\title{
ANALISIS DAMPAK TINGKAT LITERASI KEUANGAN SYARIAH, RELIGIUSITAS DAN AKSES LAYANAN TERHADAP PENGGUNAAN PRODUK KEUANGAN SYARIAH
}

\author{
Munardi*, Ahmad Fauzul Hakim Hasibuan**, Ichsan*** \\ *Universitas Malikussaleh, munardi@unimal.ac.id \\ **Universitas Malikussaleh, fauzulhakim@unimal.ac.id \\ **Universitas Malikussaleh, Ichsan84@unimal.ac.id
}

\begin{abstract}
This study used a quantitative approach involving 32 respondents from Gampong Pusong fishermen. The sampling technique was carried out using stratified random sampling. This study is based on primary data in the form of a questionnaire collected from all respondents which aims to see the impact of Islamic financial literacy on religiosity and service accents on the use of Islamic financial products. This is due to the privilege of Aceh province as a locomotive for sharia finance with the issuance of qonun no 11 of 2018 concerning Islamic finance. Methods of data analysis using Multiple Linear Regression analysis with F-test and T-test. Whereas for testing the instrument using the validity test, reliability test, and classical assumption test. The results of the study can be concluded that the regression model has been made to determine the area of rejection of the hypothesis. The rejection area is if Fcount> Ftable, namely 18.041> 2.71, then the decision $\mathrm{Ho}$ is rejected. Or it can be seen from the significance value, namely if the $\mathrm{p}$-value $<\alpha,(0.000<0.05)$, then $\mathrm{Ho}$ is rejected. So that Islamic Financial Literacy (X1), Religiosity (X2), and Access Affordability (X3) together affect Product Use $(Y)$ or the model that has been made is correct.
\end{abstract}

Keywords : Sharia Financial Literacy, Religiosity, Service Access, Sharia Financial Product Users 


\begin{abstract}
Abstrak
Penelitian ini menggunakan pendekatan kuantitatif dengan melibatkan 32 responden nelayan gampong pusong. Teknik pengambilan sampel yang dilakukan menggunakan stratified random sampling. Penelitian ini berdasarkan data primer berupa kuesioner yang dikumpulkan dari seluruh responden yang bertujuan untuk melihat dampak dari literasi keuangan syariah religiusitas dan aksen layanan terahdap penggunaan produk keuangan syariah. Hal ini di karenakan ke istimewaan propinsi aceh sebagai lokomitif keuangan syariah dengan diterbitkannya qonun no 11 tahun 2018 tentang keuangan syariah. Metode analisis data menggunakan analisis Regresi Linear Berganda dengan uji-F dan uji-T. Sedangkan untuk pengujian instrumen menggunakan uji validitas, uji reliabilitas, dan uji asumsi klasik. Hasil penelitian dapat disimpulkan bahwa model regresi yang telah dibuat untuk mengetahui daerah penolakan hipotesis. Daerah penolakan adalah jika Fhitung $>$ Ftabel yaitu 18,041 > 2,71, maka keputusan Ho ditolak. Atau dapat dilihat dari nilai signifikansi yaitu jika p-value $<\alpha,(0,000<0,05)$, maka Ho ditolak. Sehingga Literasi Keuangan Syariah (X1),Religiusitas (X2), dan Keterjangkauan Akses $\left(X_{3}\right)$ secara bersama-sama berpengaruh terhadap Penggunaan Produk (Y) atau model yang telah dibuat sudah tepat.
\end{abstract}

Kata kunci: Literasi Keuangan Syariah, Religiusitas, Akses layanan, Pengguna Produk Keuangan Syariah 


\section{PENDAHULUAN}

Indonesia merupakan salah satu negara yang memilki populasi terbesar setelah China, India, dan Amerika. Dan Indonesia juga memiliki mayoritas muslim terbesar di dunia. Pasar keuangan di indonesia sangat berkembang pesat, selain pasar keuangan konvensional juga lahir pasar keuangan berdasarkan prinsip syariah. Dengan potensi masyarakat indonesia yang mayoritas muslim diharapkan perkembangan industri keuangan syariah juga berkembang pesat.

Berdasarkan data Otoritas Jasa Keuangan (OJK), market share dari keuangan syariah terhadap sistem keuangan di Indonesia per April 2020 mencapai 9,03\% dengan total aset keuangan syariah Indonesia-tidak termasuk saham syariah-mencapai Rp1.496,05 triliun. Pangsa pasar ini mengalami kenaikan dari posisi 2019 yang sebesar 8\%.Pemerintah Indonesia menargetkan market share keuangan syariah mampu mencapai 20\% pada rentang waktu 2023-2024.

Dalam Survei Nasional Literasi Keuangan (SNLK) 2019, tercatat tingkat inklusi keuangan konvensional naik drastis dari 65,6 persen pada 2016 menjadi 75,28 persen pada 2019. Secara nasional, tingkat inklusi keuangan naik dari 67,8 persen menjadi 76,19 persen.Pada data yang sama, tingkat literasi keuangan syariah naik tipis dari 8,1 persen menjadi 8,93 persen. Sementara konvensional dari 29,3 persen menjadi 37,72 persen. Secara nasional, tingkat literasi naik dari 29,7 persen menjadi 38,03 persen. Bila dibandingkan dengan sektor keuangan konvensianal, sektor keuangan syariah masih jauh tertinggal, oleh karena itu perlu adanya edukasi ke masyarakat.

Selain peran pemerintah dan lembaga keuangan yang terkait, dukungan dari akademisi, ulama, dan da'i muslim akan berdampak signifikan bagi peningkatan literasi keuangan syariah. Sebaliknya kedangkalan para pihak tersebut akan menjadi masalah yang cukup besar terhadap peningkatan literasi keuangan syariah jika para agen of change tidak memahami. Presentase data indeks literasi keuangan syariah berdasarkan tingkat sektoral. Perbankan menjadi penyumbang tertinggi dengan sebesar 6,63 persen, diikuti berturut-turut dengan sektor asuransi sebesar 2,51 persen, sektor pegadaian sebesar 0,02 persen, dan yang terendah dari sektor dana pensiun sebesar o persen.

Industri keuangan syariah bukan hanya bersifat profit oriented, tetapi memiliki fungsi sebagai lembaga sosial bagi masyarakat, hal ini dikarenakan industri keuangan tidak hanya memiliki kewenangan menarik dan mengelola dana masyarakat tetapi juga upaya dalam mengentaskan kemiskinan. Kehadiran Industri keuangan syariah di harapakan dapat menyentuh bagi pengusaha kecil dimana terjadi peningkatan jumlah pengusaha kecil dari waktu ke waktu. Sama halnya dengan industri keuangan konve- 
sional, indusri keuangan syariah juga menawarkan berbagai macam produk-produk yang ditawarkan berupa kredit atau pembiayaan kepada masyarakat pada bidang sektor pertanian, industri kecil, perdagangan barang dan jasa, perdagangan kecil, koperasi dan lainnya.

Nelayan termasuk dalam kategori sektor perdagangan kecil. Nelayan di indonesia dirasa perlu mendapat perhatian khusus untuk mendapatkan edukasi keuangan syariah, dengan harapan dapat mengoptimalkan keuanganya lebih baik di sektor kuangan syariah. Peran industri keuangan syariah menjadi hal yang sangat penting yang akan menjadi tolak ukur pengembangan ekonomi syariah kedepannya, karena Industri keuangan syariah lebih menembus pada kalangan masyarakat kalangan bawah.

Sektor perikanan merupakan salah satu sektor andalan Provinsi Aceh, lebih kurang 55 \% penduduk Aceh bergantung kepada sektor ini baik secara langsung maupun tidak langsung. Oleh karena itu pengembangan sektor perikanan harus menjadi salah satu prioritas pembangunan di Provinsi Aceh sehingga dapat memberikan dampak positif bagi perkembangan ekonomi secara umum di kawasan ini. Namun sayangnya khususnya kondisi perekonomian sebagaian besar nelayan Aceh da umumnya di Indonesia masih memprihatinkan..

Qanun Aceh No 11 tahun 2018 tentang Lembaga Keuangan Syariah (LKS) telah diundangkan pada tanggal 4 Januari 2019. Dalam ketentuan tersebut, 3 tahun setelah qunun syariah ini sah, seluruh lembaga jasa keuangan (LJK) di Provinsi Aceh mesti menganut prinsip syariah. Konversi seluruh perbankan konvensional yang memiliki kantor di Aceh menjadi bank syariah tentu akan lebih meningkatkan market share perbankan syariah secara nasional. Kemudian hal menjadi terobosan penting dalam membangun ekonomi Islam di Aceh. Hal ini beriringan dengan keistimewaan Aceh dalam menjalankan pelaksanaan syariat Islam.

Berdasarkan uraian latar belakang di atas maka penulis tertarik untuk melakukan penelitian tentang pengaruh tingkat literasi keuangan syariah, religiusitas, \& keterjangkauan akses layanan pada masyarakat Yogyakarta terhadap penggunaan jasa perbankan syariah, untuk itu penulis memberikan judul penelitian: Analisis Dampak Tingkat Literasi Keuangan Syariah, Religiusitas Dan Akses Layanan Terhadap Penggunaan Produk Keuangan Syariah (Studi Kasus Nelayan Gampong Pusong).

\section{LANDASAN TEORETIS}

\section{Literasi Keuangan}


Menurut Otoritas Jasa Keuangan (2019), literasi keuangan adalah rangkaian proses atau aktivitas untuk meningkatkan pengetahuan (knowledge), keyakinan (competence), dan keterampilan (skill) konsumen dan masyarakat luas sehingga mereka mampu mengelola keuangan dengan lebih baik. Sedangkan menurut Mason \& Wilson, literasi keuangan adalah kemampuan seseorang untuk mendapatkan, memahami, dan mengevaluasi informasi yang relevan untuk mengambil keputusan dengan memahami konsekuensi finansial yang ditimbulkannya (Mason and Wilson 2000)

Menurut Jump Star Coalition financial literacy is the ability to use knowledge and skills to manage financial resources effectively for lifetime financial security (Huston 2010). Literasi keuangan terjadi manakala seorang individu memiliki sekumpulan keahlian dan kemampuan yang membuat orang tersebut mampu memanfaatkan sumber daya yang ada untuk mencapai tujuan. Lebih lanjut lagi, definisi literasi keuangan sebagai proses mengukur seberapa baik individu dapat memahami dan menggunakan informasi keuangan pribadi. Seperti literasi pada umumnya, Huston mengkonseptualisasikan literasi keuangan sebagai dua dimensi, yaitu dimensi pemahaman (pengetahuan mengenai keuangan pribadi) dan dimensi penggunaan (penerapan konsep dan produk keuangan pribadi).

(Capuano and Ramsay 2012) dalam penelitiannya terdapat tiga (3) komponen penting dalam melek finansial antara lain :

a. Dasar-dasar keuangan (Money Basics)

b. Simpanan dan Perencanaan (Saving and Planning)

c. Pinjaman dan Hutang (Borrowing and debting)

d. Memahami produk keuangan (Understanding financial products)

e. Kemampuan melindungi diri sendiri (Recourse and self help)

Lusardi dan Mitchell dalam Monticone (Fornero and Monticone 2011) menngatakan bahwa literasi keuangan berpegaruh positif pada perencanaan perilaku yaitu meningkatkan kekayaan kepemilikan. Adapun tabungan pesiun, Barnheim dalam (Fornero and Monticone 2011) menujukkan dampak positif dan signifikan dari melek keuangan pada ukuran akumulasi pensiun.

Kemudian Van penelitiannya dalam (Fornero and Monticone 2011) menggunakan modul dari Survei Rumah Tangga Belanda (DHS) pada tahun 2005 telah memberikan bukti yang lebih independen dan positif dampak literasi keuangan pada akumulasi kekayaan. Faktor penentu tersebut antara lain pendapatan, usia, pendidikan, toleransi terhadap risiko, kesabaran, dan kemampuan kognitif dasar.

Howlett, dalam (Fornero and Monticone 2011) melakukan percobaan pada alumni di salah satu universitas Amerika Serikat dimana peserta diminta untuk mem- 
bayangkan bahwa mereka telah memulai pekerjaan baru dan harus memutuskan apakah mereka ingin berpartisipasi dalam rencana masa depan. Hasil menunjukkan bahwa pengetahuan keuangan dan orientasi masa depan dapat berinteraksi untuk memengaruhi keumngkinan partisipasi rencana. Orientasi masa depan didefinisikan sebagai sejauhmana potensi konsekuensi masa depan dari tindakan yang mempengaruhi hasil keputusan saat ini.

Dalam penelitian Clark, et al (2009) tentang bagaimana perilaku perencanaan pensiun karyawan di tiga (3) perusahaan besar Amerika Serikat terkait dengan pemahaman mereka terhadap rencana pensiun dan dasar finansial. Ditemukan bahwa para pekerja percaya Jamsostek dapat memberikan manfaat di awal usia, usia pensiun normal berharap untuk pensiun.

(Alessie, Van Rooij, and Lusardi 2011) dalam penelitiannya menyebutkan bahwa partisipasi pasar saham sebagai saluran keuangan memiliki dampak akumulasi kekayaan yang tinggi. Rooji menggunakan modul dari DHS 2005 studi tentang dampak melek keuangan pada partisipasi pasar saham yang menujukkan bahwa individu yang memiliki literasi keuangan yang rendah secara signifikan lebih kecil kemungkinannya untuk berinvestasi di saham. Dari data Universitas Michigan, Kimball dan Shumway dalam (Fornero and Monticone 2011) menyelidiki hubungan antara kecanggihan keuangan dan tiga aspek perilaku keuangan yang dapat dianggap sebagai kurangnya diversifikasi yaitu kurangnya diversi internasional, memegang saham, dan portofolio secara keseluruhan.

Müller and Weber (2010) menganalisis hubungan antara literasi keuangan dan perilaku investasi reksadana. Secara khusus, kecenderungan untuk mengandalkan dana yang dikelola secara aktif lebih banyak dipilih daripada dana yang dikelola secara pasif. Tingkat literasi keuangan yang lebih tinggi mengidentifikasikan respon yang baik tentang memahami peringkat kredit dan tanggung jawab pembayaran dibandingkan dengan tingkat literasi keuangan yang rendah (Fornero and Monticone 2011). Lusardi, Tufano, and Field (2009) mendefinisikan melek hutang yaitu kemampuan untuk membuat keputusan sederhana mengenai kontrak hutang (dalam pengetahuan dasar khusus tentang bunga) yang diukur dengan konteks pilihan keuangan sehari-hari.

\section{Literasi Keuangan Syariah}

Studi literasi keuangan syariah dapat dianggap sebagai konsep baru yang dibawa ke suatu negara, saat ini belum ada makna literasi keuangan syariah yang dapat diterima secara umum (M. A. Abdullah and Chong 2014). Beberapa literatur dalam penelitian ini berdasarkan pada penelitian kotemporer tentang melek keuangan. In- 
ternational Network on Financial Education (2011) secara konseptual mendefinisikan literasi keuangan syariah sebagai "kemampuan seseorang untuk menggunakan pengetahuan keuangan, keterampilan dan sikap dalam mengelola sumber daya keuangan sesuai dengan ajaran islam".

El Hawary, et all (2004) dalam (Setyawati and Suroso 2015) memberikan pengertian keuangan syariah sebagai sistem yang melekat terdiri dari berbagi risiko (Risk-Sharing), materialitas (Materiality), tidak ada eksploitasi (No Exploitation), dan tidak ada pembiayaan non halal. Ada banyak hal yang dikaji dalam islam berkenaan dengan keuangan syariah diantaranya produk dan layanan perbankan syariah, lembaga keuangan islam, takaful, dan pasar modal. (Mohamed Sharif (2012) dalam (R. Abdullah and Razak 2015) mempelajari efek tidak langsung dari kualitas layanan dan kualitas produk terhadap kepuasan nasabah bank Islam di Brunei Darussalam. Penelitian tersebut mengatakan bahwa konsumen sadar akan produk dan layanan perbankan syariah. Apadun alasan mereka memilih perbankan syariah dikarenaka profitabilitas dan prinsip-prinsip agama.

Teradapat beberapa kewajiban yang dilaksanakan dalam keuangan islam seperti zakat, transaksi syariah dan investasi, wakaf, manajemen properti sesuai dengan prinsip-prinsip hukum dalam ajaran islam. (Rahim, Rashid, and Hamed (2016) berpendapat bahwa literasi keuangan islam mencakup aspek keuangan yang lebih luas yaitu 1) Dasar keuangan atau manajemen kekayaan, 2) perencanaan keuangan, 3) sumbangan amal, wakaf dan sedekah, dan 4) zakat dan hukum waris.

\section{Religiusitas}

Istilah religiusitas (religiosity) berasal dari bahasa inggris "religion" yang berarti agama, kemudian menjadi kata sifat "religios" yang berarti agamis atau saleh. Religiusitas adalah kedalaman seseorang dalam meyakini suatu agama dengan disertai tingkat pengetahuan terhadap agamanya yang diwujudkan dalam pengalaman nilainilai agama yakni mematuhi aturan dan menjalankan kewajiban dengan keikhlasan hati dalam kehidupan sehari-hari yang berkaitan dengan ibadah (Jalaudin 2010).

Religiusitas dapat diartikan sebagai seberapa jauh pengetahuan, seberapa kokoh keyakinan, seberapa pelaksanaan ibadah dan kaidah dan seberapa dalam penghayatan atas agama yang dianutnya. Bagi seorang muslim, religiusitas dapat diketahui dari seberapa jauh pengetahuan, keyakinan, pelaksanaan, dan penghayatan atas agama islam (Nashori and Rachmy Diana Mucharam 2002)

\section{Inklusi Keuangan}

Inklusi keuangan sebagai akses yang dimiliki oleh rumah tangga dan terhadap 
penggunaan produk dan layanan jasa keuangan secara efektif, produk dan layanan jasa keuangan tersebut harus tersedia secara berkelanjutan dan teregulasi dengan baik (CGAP 2016)

Inklusi keuangan sebagai akses terhadap produk keuangan yang sesuai termasuk kredit, tabungan, asuransi, dan pembayaran, tersedianya akses yang berkualitas termasuk kenyamanan, keterjangkauan, kesesuaian dan dengan memperhatikan perlindungan konsumen, serta ketersediaan tersebut juga diberikan kepada semua orang (Cheston et al. 2016). Dilain sisi Inklusi keuangan sebagai akses juga dikatakan berpengaruh terhadap penggunaan produk dan layanan jasa keuangan yang bermanfaat dan dapat dijangkau dalam memenuhi kebutuhan masyarakat maupun usahanya dalam hal ini transaksi, pembayaran, tabungan, kredit dan asuransi yang dibutuhkan oleh masyarakat secara berkelanjutan (Demirgüç-Kunt, Klapper, and Singer 2017)

AFI (2010) mengatakan bahwa inklusi keuangan juga tidak lepas dari seberapa besar kualitasnya terhadap masarakat, dalam hal ini kualitas merupakan kesesuaian produk dan layanan jasa keuangan dengan kebutuhan masyarakat dapat dilihat dari data penggunaan masyarakat yang sudah didapatkan. Selain itu kualitas juga dapat diartikan sebagai pilihan yang sudah tersedia bagi masyarakat, serta dilihat dari pemahaman konsumen terhadap produk dan layanan jasa keuangan (World Bank Group 2015)

\section{Keuangan Syariah}

Sistem keuangan adalah suatu aturan yang menjelaskan sumber-sumber dana keuangan bagi negara dalam proses alokasi dana tersebut bagi kehidupan masyarakat (Marthon 2004).Peran utama sistem keuangan adalah mendorong alokasi efesiensi sumber daya keuangan dan sumber daya riil untuk berbagai tujuan dan sasaran yang beraneka ragam (Iqbal and Mirakhor 2008).

Sistem keuangan merupakan tatanan perekonomian dalam suatu negara yang berperan melakukan aktifitas jasa keuangan yang diselenggarakan oleh lembaga keuangan. Tugas utama sistem keuangan adalah sebagai mediator antara pemilik dana dengan pengguna dana yang digunakan untuk membeli barang atau jasa serta investasi. Oleh karena itu peranan sistem keuangan sangat vital dalam mendorong pertumbuhan ekonomi, serta mampu memprediksi perkembangan perekonomian dimasa yang akan datang (Soemitra 2010)

Pengertian sistem keuangan shari'ah merupakan sistem keuangan yang menjembatani antara pihak yang membutuhkan dana dengan pihak yang kelebihan dana melalui produk dan jasa keuangan yang sesuai dengan prinsip-prinsip shari'ah. Tujuan utama sistem keuangan shari'ah adalah: menghapus bunga dari semua transaksi 
keuangan dan menjalankan aktifitasnya sesuai dengan prinsip-prinsip shari'ah, distribusi kekayaan yang adil dan merata, kemajuan pembangunan ekonomi (Lewis and Latifa M. Algoud 2007).

Pada penelitian yang terdahulu seperti penelitan yang dilakukan oleh Diana Djuwita dan Ayus Ahmad Yusuf (2018) Metode deskriptive survey dan explanatory survey, sampel 31 responden pedagang kaki lima (UMKM) di kawasan Masjid Raya At-Taqwa Cirebon. Hasil penelitan memperlihatkan Tingkat literasi kuangan syariah dikalangan UMKM (pedagang) dikawasan Masjid At-Taqwa termasuk dalam kategori less literate. hanya variabel lama usaha dan jumlah karyawan yang berpengaruhsignifikan terhadap financial knowledge. Dan hanya financcial bihavior saja yang mempengaruhi perkembangan usaha para pedagang kaki lima. Dari penelitian tersebut belum memperlihatkan variabel religiusitas.

Kemudian penelitian sebelumnya yang dilakukan oleh Hasibuan and Winaro (2018). Perlu adanya lembaga keuanngan syariah di tengah-tengan nelayan desa Pahwalan, dalam upaya peningkatan literasi keuangan syariah kepada masyarakat kalangan bawah khususnya nelayan maka diperlukan perhatian khusus oleh pemerintah daerah dan lembaga keuangan mikro syariah yang bersangkutan tentang pentingnya akses jasa keuangan syariah, layanan keuangan syariah, dan pengelolaan keuangan syariah yang baik. Hal ini belum didukung oleh aspek kebijakan peraturan yang sama dengan di propinsi aceh.

Kerangka berfikir merupakan sarana pendukung untuk lebih fokus pada tujuan penelitian melalui model (Osano and Languitone 2015). Berikut merupakan model dalam penelitian ini:

\section{Gambar 1 Kerangka Berfikir}

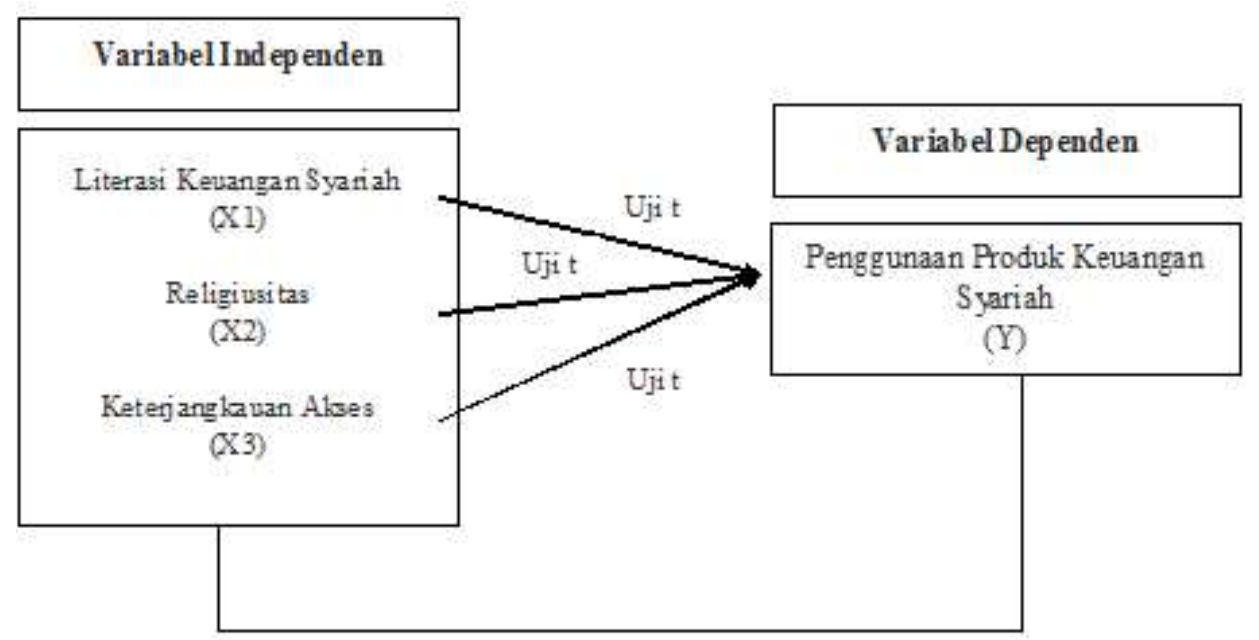

$\mathrm{Uji} \mathrm{F}$ 


\section{METODE}

Yang menjadi objek penelitian adalah tingkat literasi keuangan syariah, religiusitas, akses layanan dan penggunaan produk keuangan syariah. Penelitian ini dilaksanakan di kecamatan Banda Sakti kota Lhokseumawe tepatnya pada perkampungan nelayan gampong pusong lama

Populasi penelitian ini adalah keseluruhan nelayan perikanan tangkap yang berada di kecamatan Banda Sakti yang berdomisili di Gampong Pusong Lama dan bermata pencaharian sebagai nelayan tangkap. Sampel penelitian adalah masyarakat nelayan perikanan tangkap. Dalam penelitian ini sampel yang akan diambil adalah seluruh nelayan gampong pusong lama sebanyak 32 orang dengan teknik menggunakan metode sampel jenuh. Metode sampel jenuh adalah teknik penentuan sampel bila semua anggota populasi digunakan menjadi sampel.

Uji validitas digunakan untuk mengukur valid atau tidaknya suatu kuesioner. Suatu kuesioner dikatakan valid apabila pertanyaan pada kuesioner mampu untuk mengungkapkan sesuatu yang akan diukur oleh kuesioner tersebut (Ghozali 2011).

Uji validitas pada penelitian ini menggunakan rumus:

$$
r_{x y}=\frac{n \sum x_{i} y_{i}-\left(\sum x_{i}\right)\left(\sum y_{i}\right)}{\sqrt{\left.\left\{\left(n \sum x_{i}^{2}-\sum x_{i}\right)^{2}\right\}\left\{n \sum y_{i}^{2}-\sum y_{i}\right)^{2}\right\}}}
$$

$$
\begin{array}{ll}
\text { Keterangan : } \\
r_{x y} \quad: \text { Koefesien korelasi } \\
\mathrm{x} & : \text { Nilai total jawaban masing-masing nomor dari responden } \\
\mathrm{y} & : \text { Total butir dari jawaban responden } \\
\sum x & : \text { Jumlah skor butir } \\
\sum y & : \text { Jumlah skor total } \\
\mathrm{n} & : \text { Jumlah sampel }
\end{array}
$$

Pengujian menggunakan dua sisi dengan taraf signifikansi $(\alpha)=5 \%$ Kriteria pengujian adalah sebagai berikut:

a) Jika $r_{\text {hitung }}>r_{\text {tabel }}$ maka instrumen yang digunakan valid

b) Jika $r_{\text {hitung }}<r_{\text {tabel }}$ maka instrumen yang digunakan tidak valid 
Uji reliabilitas digunakan untuk mengukur suatu kuesioner yang merupakan indikator dari variabel atau konstruk. Suatu kuesioner dikatakan reliabel atau handal apabila jawaban responden atas pernyataan itu konsisten atau stabil dari waktu ke waktu (Ghozali 2011).Untuk mengetahui tingkat reliabilitas dari kuesioner maka dilakukan uji reliabilitas dengan rumus Cronbach's Alpha sebagai berikut

Dalam penentuan tingkat reliabilitas,suatu instrumenpenelitian dapat diterima bila dalam kisaran Cronbach's Alpha lebih dari 0,60 sampai dengan 0,80 dianggap baik atau reliabel,serta dalam kisaran lebih dari 0,80 s/d 1,00 dianggap sangat baik atau sangat reliabel. Kemudian dengan menggunakan Uji Asumsi Klasik dengan tahapan uji Uji Normalitas Uji Multikolineritas,Uji normalitas, Uji Heteroskedasitas

Analisis ini menggunakan analisis regresi linier berganda. Menurut, (Sugiyono 2014) regresi linier berganda digunakan oleh peneliti bila penelitian bermaksud meramalkan bagaimana keadaan (naik turunnya) variabel dependen, bila dua variabel independen sebagai faktor prediktor dimanipulasi (naik turunnya nilai). Analisis regresi linier berganda dilakukan untuk mengetahui arah pengaruh variabel independen terhadap variabel dependen, apakah masing-masing variabel independen berpengaruh positif atau negatif dan untuk memprediksi nilai variabel dependen apabila nilai variabel independen mengalami kenaikan atau penurunan. Rumus regresi linier berganda dalam penelitian ini yaitu (Sugiyono,2009:277):

$$
y=a+b_{1} x_{1}+b_{2} x_{2}+b_{3} x_{3}
$$

$\begin{array}{ll}\mathrm{Y} & =\text { Penggunaan Produk Keuangan Syariah } \\ \mathrm{x} 1 & =\text { Tingkat Literasi Keuangan Syariah } \\ \mathrm{x} 2 & =\text { Relgiusitas } \\ \mathrm{x} 3 & =\text { Akses Layanan } \\ \mathrm{a} & =\text { Konstanta } \\ \text { b1,b2,b3 } & =\text { Koefesien Regresi }\end{array}$

Pengujian Hipotesis dengan Uji t dan Uji F Uji t biasa dikenal dengan uji signifikansi terhadap masing-masing koefisien regresi, diperlukan untuk mengetahui signifikansi pengaruh dari masing-masing variabel independen terhadap variabel dependen yang dilihat dari interpretasi hasil di kolom Sig. Dengan dasar pengambilan keputusan (Sarjono and Julianita 2011)

1) Jika nilai probabilitas lebih kecil dari atau sama dengan nilai a (Pvalue 0,05) maka Haditerima dan Ho ditolak, artinya variabel independen berpengaruh terhadap varibael dependen. 
2) Jika nilai probabilitas lebih besar dari nilai a (Pvalue $>0,05$ ) maka Ha ditolak dan Ho diterima, artinya variabel independen tidak berpengaruh terhadap variabel dependen.

Uji Fadalah pengujian untuk melihat bagaimana pengaruh variabel independen secara simultan terhadap variabel dependen:

1) Jika nilai probabilitas lebih kecil dari atau sama dengan nilai $a($ Pvalue $<=0,05)$ maka Haditerima dan Ho ditolak, artinya variabel independen berpengaruh secara simultan terhadap variabel depeneden.

2) Jika nilai probabilitas lebih besar dari nilai a(Pvalue> 0,05) maka Haditolak dan Hoditerima, artinya variabel independen tidak berpengaruh secara simultan terhadap variabel dependen.

Jika Adjusted R2 sama dengan 1 (satu) maka variasi variabel dependen dapat dijelaskan 100 persen. Sebaliknya, jika Adjusted R2 sama dengan o (nol) maka variasi variabel dependen tidak dapat dijelaskan. Dalam penelitian ini peneliti menggunakan Adjusted R2 untuk mengukur besarnya kontribusi variabelindependen terhadap variasi variabel dependen. Setiap tambahan 1 (satu) variabel independen maka Adjusted R2 pasti meningkat.

\section{HASIL DAN PEMBAHASAN}

Persamaan regresi dalam penelitian ini digunakan untuk memprediksi nilai variabel dependen yaitu Penggunaan Produk Keuangan Syariah berdasarkan peningkatan variabel independen yaitu Literasi Keuangan Syariah, Religiusitas dan Keterjangkauan Akses. Berikut ini hasil model persamaan regresi yang dibentuk dalam penelitian ini:

Tabel 1 Uji Persamaan Regresi Berganda

\begin{tabular}{|c|c|c|c|c|c|c|}
\hline \multicolumn{7}{|c|}{ Coefficients ${ }^{a}$} \\
\hline & \multirow{2}{*}{ Model } & \multicolumn{2}{|c|}{$\begin{array}{c}\text { Unstandardized } \\
\text { Coefficients }\end{array}$} & \multirow{2}{*}{$\begin{array}{c}\begin{array}{c}\text { Standardized } \\
\text { Coefficients }\end{array} \\
\text { Beta }\end{array}$} & \multirow{2}{*}{$\mathrm{T}$} & \multirow{2}{*}{ Sig. } \\
\hline & & B & $\begin{array}{l}\text { Std. } \\
\text { Error }\end{array}$ & & & \\
\hline \multirow[t]{4}{*}{$\overline{1}$} & (Constant) & -1.074 & 2.383 & & -.450 & .656 \\
\hline & $\begin{array}{l}\text { LITERASI KEUANGAN } \\
\text { SYARIAH }\end{array}$ & .174 & .087 & .317 & 2.010 & .055 \\
\hline & RELIGIUSITAS & .161 & .066 & .412 & 2.425 & .023 \\
\hline & $\begin{array}{l}\text { KETERJANGKAUAN } \\
\text { AKSES }\end{array}$ & .232 & .095 & .304 & 2.448 & .021 \\
\hline
\end{tabular}

a. Dependent Variable: PENGGUNAAN PRODUK

Sumber : Data Primer Diolah Dengan SPSS 20, 2020 
Berdasarkan tabel 1 diketahui bahwa nilai taksiran parameter model persamaan regresinya adalah sebagai berikut:

$$
\begin{gathered}
\mathrm{Y}=-1,074+0,174 \text { Literasi Keuangan Syariah }+0,161 \text { Religiusitas }+0,232 \\
\text { Keterjangkauan Akses }+\mathrm{e}
\end{gathered}
$$

Berdasarkan persamaan regresi tersebut dapat dianalisis sebagai berikut:

1. Konstanta sebesar -1,074 artinya jika variabel Literasi Keuangan Syariah (X1), Religiusitas (X2), dan Keterjangkuan Akses (X3) bernilai o (konstan), maka skor Penggunaan Produk Keuangan Syariah sama dengan skor konstanta yaitu $-1,074$

2. Koefisien regresi variabel Literasi Keuangan (X1) adalah 0,174 artinya bahwa setiap kenaikan skor variabel Literasi Keuangan Syaraiah satu satuan, dengan asumsi variabel lain dianggap konstan maka skor variabel penggunaan produk akan naik sebesar 0,174 .

3. Koefisien regresi variabel Religiusitas (X2) adalah 0,161 artinya bahwa setiap kenaikan skor variabel Religiusitas satu satuan, dengan asumsi variabel lain dianggap konstan maka skor variabel penggunaan produk akan naik sebesar 0,161 .

4. Koefisien regresi variabel Keterjangkauan Akes (X3) adalah 0,232 artinya bahwa setiap kenaikan skor variabel Religiusitas satu satuan, dengan asumsi variabel lain dianggap konstan maka skor variabel penggunaan produk akan naik sebesar 0,232 .

Penelitian ini melakukan pengujian hipotesis untuk mengukur seberapa jauh variabel independen (Litarasi Keuangan Syariah, Religiusitas, Keterjangkauan Akses) dalam menjelaskan variabel dependen (Penggunaan Produk Keuangan Syariah). Pengujian ini dilakukan dengan memebandingkan nilai Thitung dengan Ttabel atau Pvalue dengan a. Jika Thitung > Ttabel atau P-value < a maka, H1 diterima dan sebaliknya Ho ditolak. Berikut ini tabel hasil uji hipotesis (uji t): 
Tabel 2 Hasil Uji $t$

Coefficients $^{\mathrm{a}}$

\begin{tabular}{|c|c|c|c|c|c|c|}
\hline \multirow{2}{*}{\multicolumn{2}{|c|}{ Model }} & \multicolumn{2}{|c|}{$\begin{array}{c}\text { Unstandardized } \\
\text { Coefficients }\end{array}$} & \multirow{2}{*}{$\begin{array}{c}\begin{array}{c}\text { Standardized } \\
\text { Coefficients }\end{array} \\
\text { Beta }\end{array}$} & \multirow{2}{*}{$\mathrm{T}$} & \multirow{2}{*}{ Sig. } \\
\hline & & \multirow{2}{*}{$\frac{B}{-1.074}$} & \multirow{2}{*}{$\begin{array}{c}\begin{array}{c}\text { Std. } \\
\text { Error }\end{array} \\
2.383\end{array}$} & & & \\
\hline$\overline{1}$ & (Constant) & & & & -.450 & .656 \\
\hline & LITERASI & & & & & \\
\hline & $\begin{array}{l}\text { KEUANGAN } \\
\text { SYARIAH }\end{array}$ & .174 & .087 & .317 & 2.010 & .055 \\
\hline & RELIGIUSITAS & .161 & .066 & .412 & 2.425 & .023 \\
\hline & $\begin{array}{l}\text { KETERJANGKAUAN } \\
\text { AKSES }\end{array}$ & .232 & .095 & .304 & 2.448 & .021 \\
\hline
\end{tabular}

a. Dependent Variable: PENGGUNAAN PRODUK

Sumber : Data Primer Diolah Dengan SPSS 20, 2020

Berdasarkan tabel 4.17 diatas uji hipotesis (uji t) diperoleh hasil sebagai berikut:

1. Literasi Keuangan Syariah terhadap Penggunaan Produk Keuangan Syariah $\mathrm{H} 1$ : Literasi Keuangan Syariah berpengaruh positif terhadap penggunaan produk. Hasil analisis uji t untuk variabel Literasi Keuangan Syariah diperoleh nilai thitung sebesar 0,132 dan nilai ttabel pada a 5 persen adalah 1,662, maka berarti thitung $>$ ttabel $(2,010>1,688)$. Menggunakan a 5 persen berarti pvalue $<a(0,055>0,05)$. Maka dapat disimpulkan H1 diterima, karena nilai thitung $>$ ttabel dan p-value > a. Artinya Literasi Keuangan Syariah berpengaruh positif tidak signifikan terhadap Penggunaan Produk Keuangan Syariah. Hal ini dikarenakan edukasi mengenai tata cara pengelolaan yang dimiliki nelayan masih kurang dan mayoritas responden menyatakan netral tentang cara mengelola keuangan dan manfaat pengelolaan keuangan.

2. Religiusitas terhadap Penggunaan Produk Keuangan Syariah $\mathrm{H}_{2}$ : Religiusitas (Perilaku keuangan) berpengaruh positif terhadap Penggunaan Produk Keuangan Syariah Hasil analisis uji t untuk variabel Religiusitas diperoleh nilai thitung sebesar 2 dan nilai ttabel pada a 5 persen adalah 1,662, maka berarti thitung $>$ ttabel $(2,245>1,688)$. Menggunakan a 5 persen berarti $\mathrm{p}$-value $<a(0,023<0,05)$. Maka dapat disimpulkan bahwa $\mathrm{H} 2$ diterima. Artinya Religiusitas berpengaruh positif terhadap Penggunaan Produk Keuangan Syariah

3. Keterjangkauan Akses terhadap Penggunaan Produk Keuangan Syariah H3: Keterjangkauan Akses berpengaruh positif terhadap Penggunaan Produk Keuangan Syariah. Hasil analisis uji t untuk variabel Religiusitas diperoleh nilai thitung sebesar 2,448 dan nilai ttabel pada a 5 persen adalah 1,662, maka 
berarti thitung $>$ ttabel $(2,255>1,688)$. Menggunakan a 5 persen berarti p-value < a $(0,021<0,05)$. Maka dapat disimpulkan bahwa H3 diterima. Artinya, Keterjangkauan Akses berpengaruh positif terhadap Penggunaan Produk Keuangan Syariah.

Hasil analisis data responden berdasarkan kuesioner yang diuraikan diatas, dapat diketahui bahwa responden terbanyak adalah laki-laki sebanyak 25 orang (83\%), sedangkan responden perempuan 5 orang (7\%). Sehingga sektor perikanan menjadi tumpuan laki-laki. Jika responden dilihat dari segi usia, nelayan gampong pusong lama dari sebaran responden berdasarkan usia tersebar dari beberapa kategori.Berdasarkan hasil analisis yang diuraikan diatas, maka secara keseluruhan pembahasan penelitian ini adalah sebagai berikut:

1. Pengaruh Literasi Keuangan Syariah terhadap Penggunaan Produk Keuangan Syariah. Berdasarkan hasil pengujian hipotesis menunjukkan bahwa variabel Literasi Keuangan (X1) berpengaruh terhadap Penggunaan Produk. Dilihat dari hasil analisis uji t berarti thitung $>$ ttabel $(2,010<1,688)$, dan menggunakan a 5 persen berarti pvalue $<a(0,055>0,05)$. Berarti keputusannya variabel Literasi Keuangan Syariah berpengaruh positif tetapi tidak signifikan terhadap penggunaan produk keuangan syariah. Hal ini dikarenakan responden mengaku setuju mengetahui cara mengelola dan manfaat pengelolaan keuangan dengan baik tetapi mereka masih kurang edukasi mengenai lembaga keuangan produk maupun akad yang ada di lembaga keuangan syariah.

2. Pengaruh Religiusitas terhadap Penggunaan Produk Keuangan Syariah. Berdasarkan hasil pengujian hipotesis menunjukkan bahwa variabel Religiusitas berpengaruh positif terhadap Penggunaan Produk Keuangan Syariah Hasil analisis uji t untuk variabel Religiusitas diperoleh nilai thitung sebesar 2 dan nilai ttabel pada a 5 persen adalah 1,662, maka berarti thitung $>$ ttabel $(2,245$ $>1,688)$. Menggunakan a 5 persen berarti p-value < a $(0,023<0,05)$. Hal ini sesuai dengan teori dan hipotesis yang dibuat. Hal ini dikarenakan mayoritas responden beragama islam dan menerapkanna dalam kehidupan sehari-hari.

3. Pengaruh Ketersedian Akses terhadap Penggunaan Produk Keuangan Syariah. Berdasarkan hasil pengujian hipotesis menunjukkan bahwa variabel Keterjangkauan Akses berpengaruh positif terhadap Penggunaan Produk Keuangan Syariah. Hasil analisis uji t untuk variabel Religiusitas diperoleh nilai thitung sebesar 2,448 dan nilai ttabel pada a 5 persen adalah 1,662, maka berarti thitung $>$ ttabel $(2,255>1,688)$. Menggunakan a 5 persen berarti p-value $<a(0,021<0,05)$. Hal ini sesuai dengan teori dan hipotesis yang telah dibuat. Banyak responden yang menyatakan bahwa ketersedian akses keuangan di wilayah tempat tinggal responden sudah memadai karena di 
dukung oleh penerapan Qanun no 11 tahun 2018 tentang keuangan syariah yang menerapkan seluruh lembaga keuuangan menerapkan prinsip syariah dalam kegiatan keuangan

\section{SIMPULAN}

Hasil penelitian menunjukkan bahwa Tingkat Literasi Keuangan Syariah secara parsial mempunyai pengaruh yang positif tetapi tidak signifikan terhadap penggunaan produk keuangan syariah pada nelayan gampong Pusong lama kecamatan Banda Sakti. Hal ini berbeda dengan penelitian yang dilakukan oleh Hasibuan and Winaro (2018) tidak terdapat perbedaan terhadap literasi keuangan syariah pada pada nelayan desa Pahlawan kecamatan Tanjung tiram kabupaten Batubara. Adanya pengetahuan, sikap dan implementasi seseorang dalam mengelola keuangan akan membantu tercapai sebuah kesejahteraan dalam hal finansial tentunya.

Hasil penelitian menunjukan bahwa Religiusitas secara parsial mempunyai pengaruh yang positif dan signifikan terhadap penggunaan produk keuangan syariah pada nelayan gampong Pusong lama kecamatan Banda Sakti. Seseorang yang memiliki tingkat religiusitas yang tinggi akan memiliki kecenderungan akan memperhatikan aspek agama dalam setiap pengambilan keputusannya.

Hasil penelitian menunjukkan bahwa keterjangkauan askes layanan secara parsial mempunyai pengaruh positif dan signifikan terhadap penggunaan produk keuangan syariah pada nelayan gampong Pusong lama kecamatan Banda Sakti . Kemudahan dalam mengakses layanan sangat mempengaruhi keputusan masyarakat dalam penggunaan jasa perbankan syariah.

Hasil penelitian menunjukan bahwa Tingkat Literasi Keuangan Syariah, Religiusitas, dan Keterjangkauan Akses Layanan secara simultan berpengaruh signifikan terhadap pada nelayan gampong Pusong lama kecamatan Banda Sakti.

Berdasarkan kesimpulan dan hasil penelitian, maka peneliti mengajukan beberapa saran bagi industri perbankan syariahdan berbagai pihak terkait seperti BI dan OJK, perlu adanya peningkatan sosialisasi kepada masyarakat tentang pengelolaan keuangan yang baik serta edukasi terkait manfaat dan resiko produk lembaga keuangan. Kemudian perlu adanya pengembangan dan penambahan sarana lembaga keuangan baik berupa kantor cabang, kantor kas, ATM, maupun agen - agen lembaga keuangan sehingga akses layanan dapat terjangkau oleh masyarakat hingga ke pelosok daerah.

Bagi peneliti-peneliti selanjutnya, hendaknya untuk menambahkan variabel atau indikator baru dalam penelitian yang akan datang agar dapat menghasilkan 
gambaran yang lebih luas tentang masalah penelitian yang sedang diteliti. Dan dengan menambahkan sampel yang lebih banyak, sehingga hasil analisis dari penelitian yang akan didapatkan lebih akurat.

\section{PUSTAKA ACUAN}

Abdullah, Mohamad Azmi, and Rosita Chong. 2014. "Financial Literacy: An Exploratory Review of the Literature and Future Research." Journal of Emerging Economies and Islamic Research.

Abdullah, Rose, and Ahmad Lutfi Haji Abdul Razak. 2015. "Exploratory Research into Islamic Financial Literacy in Brunei Darussalam." Researchgate. Net (October): 28. https://www.researchgate.net/profile/Lutfi_Abdul_Razak/ publication/283225608_Exploratory_Research_into_Islamic_Financial

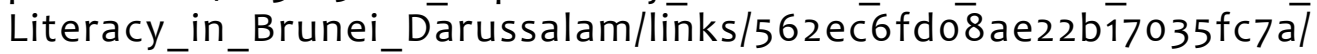
Exploratory-Research-into-Islamic-Financial-Literacy-in-Brunei-Darussalam.

AFI. 2010. The 2010 AFI Survey Report on Financial Inclusion Policy in Developing Countries.

Alessie, Rob, Maarten Van Rooij, and Annamaria Lusardi. 2011. "Financial Literacy and Retirement Preparation in the Netherlands." Journal of Pension Economics and Finance.

Capuano, Angelo, and Ian Ramsay. 2012. "What Causes Suboptimal Financial Behaviour? An Exploration of Financial Literacy, Social Influences and Behavioural Economics." SSRN Electronic Journal.

CGAP. 2016. "CGAP ANNUAL REPORT 2016 Advancing Financial Inclusion to Improve the Lives of the Poor ABOUT CGAP."

Cheston, Susy, Tomás Conde, Arpitha Bykere, and Elisabeth Rhyne. 2016. "The Business of Financial Inclusion: Insights from Banks in Emerging Markets." Accion: Center for Financial Inclusion (July): 1-67. https://www. centerforfinancialinclusion.org/the-business-of-financial-inclusion-insightsfrom-banks-in-emerging-markets.

Demirgüç-Kunt, Asli, Leora Klapper, and Dorothe Singer. 2017. "Financial Inclusion and Inclusive Growth: A Review of Recent Empirical Evidence." Policy Research Working Paper.

Fornero, Elsa, and Chiara Monticone. 2011. "Financial Literacy and Pension Plan Participation in Italy." Journal of Pension Economics and Finance.

Ghozali, Imam. 2011. "Aplikasi Analisis Multivariate Dengan Program IBM SPSS 19 (Edisi Kelima)." Aplikasi Analisis Multivariate dengan program SPSS.

Hasibuan, Ahmad Fauzul Hakim, and Febru Winaro. 2018. "KABUPATEN BATUBARA." $3(2): 17-30$.

Huston, Sandra J. 2010. "Measuring Financial Literacy." Journal of Consumer Affairs. 
International Network on Financial Education. 2011. "Measuring Financial Literacy : Questionnaire and Guidance Notes for Conducting an Internationally Comparable Survey of Financial Literacy." Oecd.

Iqbal, Zamir, and Abbas Mirakhor. 2008. Pengantar Keuangan Islam: Teori Dan Praktek. Jakarta: Kencana.

Jalaudin. 2010. Psikologi Agama. Jakarta: PT Raja Grafindo Persada.

Lewis, Mervyn K., and Latifa M. Algoud. 2007. Perbankan Shari'ah: Prinsip, Praktik, Dan Konsep. Jakarta: Serambi.

Lusardi, A, P Tufano, and S Field. 2009. NBER Working Paper Debt Literacy, Financial Experiences, and Overindebtedness.

Marthon, Said Sa'ad. 2004. Ekonomi Islam: Di Tengah Krisis Ekonomi Global. Jakarta: Zikrul Hakim.

Mason, Carolynne, and Richard Wilson. 2000. "Conceptualising Financial Literacy." Business School Research Series.

Mohamed Sharif, Bashir. 2012. "Analysis of Customer Satisfaction with the Islamic Banking Sector : Case of Brunei Darussalam." Asian Journal of Business and Management Sciences.

Müller, Sebastian, and Martin Weber. 2010. "Financial Literacy and Mutual Fund Investments: Who Buys Actively Managed Funds?” Schmalenbach Business Review 62(2): 126-53.

Nashori, Fuad, and Rachmy Diana Mucharam. 2002. Mengetahui Kreativitas Persrektif Psikologi Islam. Yogjakarta: Menara Kudus.

Osano, Hezron Mogaka, and Hilario Languitone. 2015. "Factors Influencing Access to Finance by SMEs in Mozambique: Case of SMEs in Maputo Central Business District." Journal of Innovation and Entrepreneurship.

Rahim, Siti Hafizah Abdul, Rosemaliza Abdul Rashid, and Abu Bakar Hamed. 2016. "Islamic Financial Literacy and Its Determinants among University Students: An Exploratory Factor Analysis." International Journal of Economics and Financial Issues.

Sarjono, Haryadi, and Winda Julianita. 2011. SPSS vs LISREL Sebuah Pengantar Aplikasi Untuk Riset. Jakarta: Salemba Empat.

Setyawati, Irma, and Sugeng Suroso. 2015. "Sharia Financial Literacy And Effect On Social Economic Factors Survey On Lecturer In Indonesia." International Journal of Scientific \& Technology Research 4(8): 92-102.

Soemitra, Andri. 2010. Bank Dan Lembaga Keuangan Shari'ah. Jakarta: Kencana.

Sugiyono. 2014. Metode Penelitian Pendidikan Pendekatan Kuantitatif, Kualitatif, Dan R\&D. Bandung: alfabeta. 